\title{
KEWENANGAN PENGADILAN AGAMA DALAM MEMUTUS PEMBATALAN AKTA HIBAH
}

\author{
Annisa Setyo Hardianti \\ Kantor Notaris dan PPAT Tan Lyla Herawati., S.H., M.Hum. \\ Jalan Kauman, No. 38 Malang Jawa Timur \\ Email: setyo.annisa@yahoo.com
}

\begin{abstract}
The general understanding of grant is an act included in a legal action in which transfer of ownership rights are intentionally transferred to those or others. The grants under civil law stipulated in the Law of Civil Law or Burgelijk Wetboek (BW) in Article 1666 to Article 1693, whereas in Islamic law grants are stipulated in Islamic Law Compilation (KHI) from Article 210 to Article 214. The Principal Problems in Cancellation Deed of Grant numbers: 162 I $K L J / 11 / 1999$, where there was a mistake of judgment on the first and second claims is that the Religious Court authority to decide the case of cancellation deed grants whereas there are already rules which clearly stipulates that the Religious Court authorized in deciding the case among Muslims in Article 3 and Article 49 of Law No. 3 of 2006 which has been updated to Law Number 50 Year 2009 on Religious Courts. To the level of Final Appeal and Review of judgment turned into the Religious Court in charge of the case of cancellation of the Grant Deed. The objective to be achieved through this research is to analyze the Supreme Court ruling number: $78 \mathrm{PK} / \mathrm{Ag} / 2013$ and all processes so that there is an error the same for judges who would decide a similar case. The study was conducted using the method of juridical normative statute approach and conceptual approach which is then analyzed by using prescript. The Judge's decision that deviates from the rules of law regarding the authority of the Religious Court may result in an injustice and not achieving legal certainty, while the state has regulated it very clearly in the Act.
\end{abstract}

Key words: jurisdiction of religious court, grant deed cancelation, court judgment

\begin{abstract}
Abstrak
Pengertian hibah secara umum yaitu hibah termasuk dalam perbuatan hukum dimana terjadi pemindahan hak kepemilikan yang sengaja untuk dialihkan kepada pihak atau orang lain. Adapun hibah menurut hukum perdata diatur dalam Kitab Undang-undang Hukum Perdata atau Burgelijk Wetboek (BW) dalam Pasal 1666 sampai dengan Pasal 1693, sedangkan dalam hukum Islam hibah diatur dalam Kompilasi Hukum Islam (KHI) mulai dari Pasal 210 hingga Pasal 214. Dalam Pokok Permasalahan pembatalan Akta Hibah nomor: 162/Klj/11/1999, dimana terjadi suatu kesalahan yaitu putusan pada tingkat pertama dan kedua menyatakan bahwa Pengadilan Agama tidak berwenang untuk memutus perkara pembatalan Akta Hibah tersebut sedangkan sudah ada aturan yang dengan jelas mengatur bahwa Pengadilan Agama berwenang dalam memutus perkara diantara umat Islam atau muslim dalam Pasal 3 dan Pasal 49 Undang-Undang Nomor 3 Tahun 2006 yang telah diperbarui menjadi Undang-Undang Nomor 50 Tahun 2009 tentang Peradilan Agama. Hingga pada tingkat Kasasi dan Peninjauan Kembali putusan berubah menjadi Pengadilan Agama berwenang atas perkara pembatalan Akata Hibah tersebut. Adapun tujuan yang ingin dicapai melalui penelitian ini adalah untuk
\end{abstract}


menganilisis putusan Mahkamah Agung nomor: $78 \mathrm{PK} / \mathrm{Ag} / 2013$ beserta segala proses sehingga tidak terjadi suatu kesalahan yang sama bagi para hakim yang kelak memutus perkara serupa. Penelitian dilakukan menggunakan metode yuridis normatif dengan metode pendekatan perundang-undangan (statute approach) dan pendekatan konsep (conceptual approach) yang kemudian dianalisis dengan menggunakan teknik preskripif. Putusan Hakim yang menyimpang dari aturan perundang-undangan mengenai kewenangan Pengadilan Agama mengakibatkan terjadinya suatu ketidakadilan dan tidak tercapainya suatu kepastian hukum, sedangkan negara telah mengatur dengan sangat jelas dalam Undang-undang.

Kata kunci: kewenangan pengadilan agama, pembatalan akta hibah, putusan pengadilan

\section{Latar Belakang}

Obyek hibah dapat berupa bendabenda bergerak maupun benda-benda tidak bergerak. Dalam tulisan ini Penulis membahas mengenai hibah yang obyeknya berupa benda tidak bergerak yaitu tanah dan bangunan. Berdasar pada Putusan Mahkamah Agung Nomor: 78 PK/ Ag / 2013 dengan penggugat I dan Penggugat II adalah H. Achmad Jakoen Tjokrohadi bersama istri, sedangkan tergugat I dan Tergugat II adalah Dra. Ani Hadi Setyowati yang berstatus sebagai anak dari Penggugat bersama dengan suami. permasalahan ini diangkat menjadi suatu isu hukum yang dapat dikaji lebih dalam.

Indonesia merupakan Negara dengan asas Bhineka Tunggal Ika, yang artinya walaupun bermacam-macam suku, budaya, etnis, dan agama yang ada tapi tetap satu kesatuan. Dalam hal ini tentunya Indonesia sudah merumuskan segala upaya untuk menyatukan segala perbedaan tersebut agar terciptanya keadilan dan kerukunan antar masyarakat. Salah satu alat pemersatu tersebut adalah yang biasa dikenal dengan istilah hukum,
Hukum merupakan alat pemersatu yang dapat mewujudkan cita-cita bangsa dalam perihal mewujudkan keadilan sosial dan sebagai alat kontrol masyarakat (Law as a tool of social control)

Kaidah-kaidah tersebut berupa peraturanperaturan hukum baik yang tidak tertulis maupun yang tertulis yang disertai dengan sanksi-sanksi yang tegas. Dalam setiap masyarakat akan dijumpai suatu perbedaan antara tingkah laku yang dikendaki oleh kaidah-kaidah hukum. Ada suatu keadaan yang tidak dapat dihindari, sehingga timbul suatu ketegangan karena terdapat perbedaan kepentingan ${ }^{1}$.

Banyak hal yang dapat dan perlu diatur oleh hukum di Indonesia, salah satu dari hal yang perlu diatur tersebut adalah hubingan keperdataan, melalui Hukum Perdata Pengertian Hukum Perdata menurut Salim HS yaitu keseluruhan dari kaidah hukum, baik yang tidak tertulis maupun tertulis dalam mengatur suatu hubungan antar para subjek hukum satu dengan yang lainnya tentang

1 R. Subekti, Aneka Perjanjian, (Bandung: Citra Aditya Bakti, 1995), hlm. 95.

2 Titik Triwulan Tutik, Pengantar Ilmu Hukum, (Jakarta: Prestasi Pustakaraya, 2006), hlm. 10. 
hubungan berkeluarga dan dalam pergaulan bermasyarakat ${ }^{2}$.

Ruang Lingkup hukum perdata beraneka ragam, mulai dari perikatan, perkawinan, perjanjian hingga daluarsa. Pembahasan kali ini difokuskan pada permasalahan hukum perdata mengenai perihal hibah. Pengertian hibah juga beragam, di sesuaikan dengan contoh kasus yang sedang dianalisa.

Hibah seringkali disamakan dengan peristiwa waris, padahal apabila dianalisa jauh lebih dalam maka akan diketahui bahwa hibah berbeda dengan waris. Hibah terjadi pada saat si pemberi hibah masih hidup, selama waktu pelaksanaan pemberian hibat tersebut, sedangkan apabila dalam waris akan terjadi pada saat seseorang telah meninggal dunia dengan meninggalkan harta kekayaan atau hal-hal yang dapat diwariskan. Obyek dari pemberian hibah hanya dapat dilakukan pada segala benda yang sudah ada, apabila pemberian atau penyerahan hibah dilakukan pada benda yang baru akan ada dikemudian hari, maka hibah akan menjadi batal ${ }^{3}$.

Selain itu, hibah juga dapat dijadikan sebagai salah satu solusi dalam menyelesaikan suatu masalah waris. Namun dilain sisi, dalam fakta masyarakat pemberian hibah juga dapat menimbulkan permasalahanpermasalahan hukum, sehingga tujuan hibah yang sebenarnya tidak sejalan sebagaimana mestinya. Penyelesaian jika terjadi sengketa mengenai obyek hibah terpaksa harus diselesaikan di pengadilan.
Gambaran kasus pada duduk perkara perdata tentang pembatalan Akta Hibah tersebut berawal pada tahun 11 November 1999, dimana para Penggugat yang sudah berusia lanjut tersebut dengan inisiatif Tergugat I dan Tergugat II mendatangi kantor Notaris dan PPAT Tri Sukmawati Handayani, S.H., untuk menandatangani akta hibah. Bahwa dengan segala keterbatasan para Penggugat yang telah usia lanjut dan telah mengalami banyak penurunan kondisi fisik seperti pendengaran dan penglihatan tanpa disadari bahwa itu adalah Akta yang berisi bahwa para Penggugat bersedia untuk menghibahkan tanah beserta bangunan obyek sengketa seluruhnya kepada Tergugat I.

Hal ini terjadi karena atas dasar kepercayaan seorang orangtua terhadap anaknya yang diyakini tidak akan memiliki niat buruk terhadap orangtuanya. Bahwa selanjutnya dengan adanya Akta Hibah Nomor 162/Klj/11/1999, 11 November 1999 dimanfaatkan oleh Tergugat untuk membalik nama atau mengalihkan seluruh hak kepemilikan dari tanah dan bangunan tersebut atas nama Tergugat I tersebut.

Berawal dari peristiwa itu para Penggugat yang pada akhirnya menyadari penyalahgunaan tersebut para Penggugat menempuh jalur hukum melalui Pengadilan Agama Kota Malang dengan Putusan Nomor: 1000/Pdt.G/2011/PA.Mlg. Dikarenakan hasil dari gugatan tersebut adalah ditolak karena dianggap bahwa Pengadilan Agama

3 R. Subekti, Aneka Perjanjian, (Bandung: Citra Aditya Bakti, 1995), hlm. 95. 
tidak berwenang secara absolut dalam memutus perkara hibah tersebut, maka dilakukan Banding oleh Penggugat melalui Pengadilan Tinggi Agama dalam putusan nomor: 48/Pdt.G/2012/PTA.Sby dengan hasil mengabulkan permohonan banding namun menguatkan putusan Pengadilan Agama yang mengungkapkan bahwa Pengadilan Agama tidak berhak untuk mengadili perkara hibah tersebut.

Putusan pada tingkat pertama di Pengadilan Agama kota Malang dirasa tidak sesuai dengan Pasal 49 Undang-undang Nomor 7 Tahun 1989 tentang Peradilan Agama sebagaimana telah diubah dengan Undang-undang Nomor 3 Tahun 2006, dan perubahan kedua dengan Undang-undang Nomor 50 Tahun 2009 yang menyebutkan "Pengadilan Agama bertugas dan berwenang menyelesaikan perkara-perkara di tingkat pertama antara orang-orang yang beragama Islam di bidang kewarisan, wasiat dan hibah yang dilakukan berdasarkan hukum Islam”, berdasarkan fakta hukum dan Akta Hibah terbukti Pemberi Hibah dan Penerima Hibah beragama Islam.

Maka berlanjut pada tingkat Kasasi di Mahkamah Agung Putusan Nomor: 492 K/ AG/2012 yang mengabulkan gugatan para Penggugat sebagian dengan menyatakan bahwa Akta Hibah Nomor 162/Klj/11/1999 tanggal 11 November 1999 yang di buat oleh PPAT Malang Tri Sukmawati Handayani, S.H., batal demi hukum. Berdasarkan keputusan tersebut maka secara implisit putusan tingkat
Kasasi tersebut menyatakan Pengadilan Agama berwenang dalam memutus perkara pembatalan Akta Hibah tersebut.

Hingga berlanjut pada Peninjauan Kembali yang kali ini pemohon peninjauan kembali adalah dari pihak Tergugat I dan pihak Tergugat II, yang hasilnya dikuatkan dengan Putusan Mahkamah Agung Nomor: $78 \mathrm{PK} / \mathrm{Ag} / 2013$ dengan hasil menolak permohonan peninjauan kembali dari para Pemohon Peninjauan Kembali yaitu Dra. Ani Hadi Setyowati. Dikatakan bahwa adanya kesalahan terhadap judex yuris oleh para Tergugat yang tidak dapat dibenarkan oleh Hakim. Sehingga Hakimpun berpendapat bahwa judex yuris atau putusan setingkat Mahkamah Agung sudah tepat dan benar dalam memutus perkara tersebut.

Berdasarkan latar belakang dan runtutan masalah yang telah dijelaskan maka peneliti akan membahas lebih dalam mengenai dasardasar hukum dan permasalahan-permasalahan yang ada berkaitan dengan kewenangan Pengadilan Agama dalam memutus perkara hibah karena seperti yang sudah dijelaskan adanya putusan pada tingkat pertama dan kedua yang menyimpangi aturan Pasal 49 Undang-undang Nomor 3 Tahun 2006 yang telah diperbarui dengan Undang-undang Nomor 50 Tahun 2009 tentang Peradilan Agama, serta dalam perihal pengetahuan tentang aturan-aturan hibah yang sesuai dengan aturan dalam Undang-undang.

Selain itu peneliti juga akan membahas mengenai hibah dari sudut pandang Islam, karena hibah tidak dapat dilepaskan dari Hibah secara Islam, hal ini perlu dibahas 
secara bersamaan karena hibah tidak hanya ada dalam BW (Burgelijk Wetboek) tetapi juga diatur di dalam Kompilasi Hukum Islam (KHI) sesuai dengan syariat Islam.

Berdasarkan latar belakang yang telah diuraikan, maka dapat dirumuskan permasalahan sebagai berikut:

1. Apakah faktor atau syarat yang membuat Putusan PengadilanAgamaberbeda antara tingkat Gugatan hingga Banding dengan putusan pada tingkat Kasasi hingga Peninjauan Kembali Putusan Mahkamah Agung Nomor: 78 PK/Ag/2013 sehingga terjadi penolakan pembatalan akta Hibah apabila ditinjau dari aturan Perundangundangan mengenai Peradilan Agama?

2. Bagaimanakah keabsahan Akta Hibah Nomor: 162/Klj/11/1999 apabila ditinjau dari sudut pandang Kompilasi Hukum Islam?

Untuk mengetahui dan menganalisis kewenangan dari Pengadilan Agama dalam memutus suatu perkara hibah yang dalam pembahasan kali ini adalah perihal pembatalan Akta Hibah, dan sejauh mana Pengadilan Agama dapat menindak lanjuti peristiwa perkara hukum tersebut. Sehingga dapat menghasilkan sebuah output berupa pemecahan masalah tersebut.

Teori yang digunakan dalam penelitian ini adalah yang pertama Teori Kewenangan, guna mengkaji mengenai kewenangan yang dimiliki oleh Pengadilan Agama dalam memutus perkara pembatalan Akta Hibah Nomor 162/ Klj/11/1999. Lalu yang kedua Teori Keadilan, dalam teori ini digunakan untuk mengkaji mengenai keadilan yang ditimbulkan akibat adanya kesalahan dalam memutus perkara pembatalan Akta Hibah tersebut.

Selanjutnya ketiga adalah Teori tentang kepastian hukum yang digunakan untuk mengkaji tentang adanya kesalahan dalam putusan hakim yang tidak sesuai dengan Peraturan Perundang-undangan sehingga menimbulkan keraguan akan kepastian dalam aturan yang sudah tegas diatur dalam Undangundang. Pada teori keempat yang digunakan yaitu Teori Pertanggung jawaban hukum ini lebih ditujukan bagi para pihak, setelah Akta Hibah Nomor 162/Klj/11/1999 dinyatakan batal demi hukum tentunya menimbulkan suatu akibat bagi para pihak yang bersangkutan, sehingga perlu adanya pertanggungjawaban dari masing-masing pihak.

Dalam penulisan ini digunakan metode yuridis-normatif, dengan jenis pendekatan Udang-undang (statute approach) dan pendekatan konseptual (conceptual approach). Melalui metode tersebut maka dapat diketahui bahwa cara pandang hakim dari sudut pandang suatu kasus dapat membuat suatu putusan Pengadilan tidak sesuai dengan aturan yang ada dalam sebuah perundangundangan. Putusan Hakim yang menyimpang dari aturan perundang-undangan mengenai kewenangan dari Pengadilan Agama dapat berakibat terjadinya suatu ketidakadilan dan tidak tercapainya suatu kepastian hukum, sedangkan negara telah mengatur dengan sangat jelas dalam Undang-undang ${ }^{4}$.

4 Abdulkadir Muhammad, Hukum dan Penelitian Hukum, (Bandung: Citra Aditya Bakti, 2004), hlm. 57. 
Dalam penelitian hukum tidak dikenal adanya data, sebab dalam penelitian hukum khususnya yuridis normatif sumber penelitian hukum diperoleh dari kepustakaan bukan dari lapangan, untuk itu istilah yang dikenal adalah bahan hukum 5 .

Bahan hukum primer merupakan bahan hukum yang memiliki sifat autoratif yang artinya memiliki sebuah otoritas. Ada pula bahan hukum primer, yaitu:

a. Undang-Undang Dasar NRI Tahun 1945.

b. Pasal 1666 hingga Pasal 1693 Kitab Undang-undang Hukum Perdata (KUHPer).

c. Pasal 210 hingga Pasal 214 Kompilasi Hukum Islam.

d. Undang-undang Nomor 50 Tahun 2009 Tentang Peradilan Agama (Lembaran Negara Republik Indonesia Tahun 2009, Tambahan Lembaran Negara Republik Indonesia Nomor 5078).

e. Putusan Mahkamah Agung nomor 78 $\mathrm{PK} / \mathrm{Ag} / 2013$.

Penelitian ini menggunakan pengolahan bahan hukum dengan cara editing, yaitu pemeriksaan kembali bahan hukum yang diperoleh terutama dari segi kelengkapannya, kejelasan makna, kesesuaian, serta relevansinya dengan pembahasan atau kelompok yang lain. Setelah bahan hukum terkumpul dan dirasa lengkap maka bahan hukum tersebut dianalisis untuk mendapatkan hasil akhir, dengan teknik analisis bahan hukum content analysis.
Sehingga dapat disimpulkan suatu pelaksanaan hukum tidak cukup hanya dengan suatu aturan yang yang telah mengatur sebuah persoalan tertentu, namun kemampuan dan pemahaman seorang Hakim dalam beracara serta pemahaman para pihak akan aturan tersebut juga perlu untuk diperhatikan agar tidak terjadi suatu penyimpang dalam praktek di tengah masyarakat.

\section{Pembahasan}

Persoalan hibah itu sendiri dalam KUHPerdata telah ada dan diatur mulai dari Pasal 1666 sampai dengan Pasal 1693 KUHPerdata. Dikatakan dalam Pasal 1666 KUHPerdata arti dari hibah adalah "Hibah adalah sebuah perjanjian dengan penghibah, semasa hidupnya, dengan cuma-cuma dan dengan tidak dapat ditarik kembali, menyerahkan sesuatu benda guna keperluan si penerima hibah yang menerima penyerahan itu.Undang-undang tidak akan mengakui lainlain hibah selain hibah-hibah diantara orangorang yang masih hidup" ${ }^{\circ}$.

Hal yang sama termasuk mengenai obyek hibah juga ada dan diatur dalam pasal selanjutnya yaitu Pasal 1667 KUHPerdata yang berbunyi “ hibah hanya dapat mengenai benda-benda yang sudah ada. Jika hibah itu meliputi benda-benda yang baru akan ada di kemudian hari, maka sekedar mengenai itu hibahnya adalah batal"'.

5 Peter Mahmud Marzuki, Pengantar Ilmu Hukum, (Jakarta: Kencana, 2011), hlm. 136.

6 R. Subekti, R. Tjitrosudibio, Kitab Undang-Undang Hukum Perdata, (Jakarta: Pradnya Paramita, 1979), hlm. 436.

7 Ibid., hlm. 436. 
Pasal mengenai hibah haruslah dicermati dengan seksama, ditinjau dari Pasal 1666 KUHPerdata bahwa hibah merupakan perjanjian sepihak yang dilakukan dengan cuma-cuma atau sukarela dan tidak dapat ditarik kembali, namun hal ini bukan ssesuatu yang mutlak. Terdapat beberapa pengecualian yang diatur dalam Pasal 1688 KUHPerdata yang dapat membuat suatu hibah tersebut dapat ditarik kembali oleh Pemberi Hibah atau dengan kata lain dapat dibatalkan oleh si Pemberi Hibah.

Selain itu sesuai aturan dalam Pasal 1 ayat (1) yang mengatakan bahwa Peradilan Agama merupakan peradilan bagi orang-orang yang beragama Islam. UU Nomor 7 Tahun 1989 Tentang Peradilan Agama sebagaimana telah diubah dan ditambah dengan UU Nomor 3 Tahun 2006 dan UU Nomor 50 Tahun 2009, Pasal 2 yang tertulis: "Peradilan Agama merupakan salah satu dari pelaksana kekuasaan kehakiman bagi rakyat beragama Islam yang mencari keadilan mengenai perkara perdata tertentu yang diatur dalam undang-undang ini”.

Berdasarkan aturan tersebut, maka dirasa tepat apabila para Penggugat melakukan gugatan melalui Kepaniteraan Pengadilan Agama kota Malang, mengingat fakta mengatakan bahwa kedua belah pihak yaitu Penggugat dan Tergugat merupakan umat islam, maka tidak ada alasan lain untuk para pihak tidak mengikuti aturan syari'at Islam sesuai dengan kepercayaan yang diyakini.
Terlebih dalam Pasal 49 Undangundang Nomor 3 Tahun 2006 yang kini telah diperbarui dengan Undang-undang Nomor 50 Tahun 2009 yang mengatakan bahwa Pengadilan agama bertugas dan berwenang memeriksa, memutus, dan menyelesaikan perkara di tingkat pertama antara orang-orang yang beragama Islam di bidang:

a. perkawinan;

b. waris;

c. wasiat;

d. hibah;

e. wakaf;

f. zakat;

g. infaq;

h. shadaqah dan

i. ekonomi syari'ah.

Berawal dari pengajuan gugatan pada tanggal 17 (tujuh belas) Juni 2011 (dua ribu sebelas) yang terdaftar di Kepaniteraan Pengadilan Agama Malang, dikemukakan bahawa Penggugat merupakan sepasang suami dan istri yaitu H. Achmad Jakoen Tjokrohadi bin Achmad Tohir dan $\mathrm{Hj}$. Boediharti binti Notodiharjo yang dikaruniai 8 (delapan) orang anak, ialah:
a. Agoes Budianto;
b. Ani Hadi Astuti;
c. Ani Hadi Moekti Lestari;
d. Ani Hadi Setyowati (Tergugat I);
e. Agoestin Kemalawati;
f. Agus Budi Wasono;
g. Setyo Boedi Hartono;
h. Agus Heri Purnomo. 
Obyek sengketa dalam perkara ini adalah sebidang tanah dan bangunan yang merupakan Harta gono gini dan harta satu-satunya dari para Penggugat. Harta ini berwujud sebidang tanah dan bangunan yang tersebut dalam sertifikat Hak Milik (SHM) Nomor 208 dahulu atas nama AHMAD JAKOEN TJOKROHADI (Penggugat I) sekarang telah berubah menjadi atas nama Dra. Ny. ANI INDRA SUDIBYO alias ANI HADI SETYOWATI (Tergugat I).

Tanah dan bangunan ini terletak di Jl. Diponegoro No. 02, RT. 01, RW. 05, Kelurahan Klojen, Kecamatan Klojen, Kota Malang, seluas $983 \mathrm{~m} 2$ yang telah didiami oleh para Penggugat beserta anak-anaknya tersebut sejak tahun 1965.

Sudah seharusnya sebuah perjanjian dilakukan atas dasar kesepakatan dan tanpa paksaan atau tipu daya. Seperti yang diatur dalam Pasal 1320 KUHPerdata (BW) mengenai syarat sahnya perjanjian yaitu:

a. Sepakat mereka yang mengikatkan dirinya.

b. Kecakapan untuk membuat suatu perikatan.

c. Suatu hal tertentu.

d. Suatu sebab yang halal.

Tiada sepakat yang sah apabila sepakat itu diberikan karena kekhilafan, atau diperolehnya dengan paksaan atau penipuan, seperti yang diatur dalam Pasal 1321 KUHPerdata (BW). Artinya sebuah kesepakatan yang mendasari syarat sahnya sebuah perjanjian haruslah dilakukan dengan sadar dan tanpa tipu daya.
Hal inilah yang terjadi pada saat pembuatan Akta Hibah pada tanggal 11 (sebelas) Nopember 1999 (seribu sembilan ratus sembilah puluh sembilan) dimana para Penggugat yang telah berusia lanjut dan mengalami banyak penurunan fisik mulai dari penglihatan dan pendengaran diarahkan oleh para Tergugat I dan Tergugat II yaitu suami dari Tergugat I untuk menghadap PPAT di kota Malang untuk menandatangani akta yang pada akhirnya disadari oleh para Penggugat merupakan Akta Hibah Nomor: 162/Klj/11/1999.

Berdasarkan tindakan para Tergugat I dan Tergugat II yang memanfaatkan keadaan para Penggugat yang telah berusia lanjut tersebut, maka para Penggugat merasa tertipu dan pada akhirnya melaporkan tindakan tersebut kepada Kepaniteraan Pengadilan Agama kota Malang. Singkatnya bahwa dalam putusan pada tingkat pertama atau gugatan yaitu di Pengadilan Agama kota Malang dan pada tingkat Banding di Pengadilan Tinggi Agama Kota Surabaya dinyatakan bahwa Pengadilan Agama tidak berwenang untuk memutus perkara pembatalan Akta Hibah tersebut, atas dasar klausula yang ada pada perjanjian Akta Hibah tersebut.

Sedangkan dalam putusan pada tingkat Kasasi hingga Peninjauan Kembali di Mahkamah Agung Pengadilan Agama berwenang untuk memutus karena atas dasar fakta yang menyebutkan bahwa para pihak merupakan seorang muslim. 
A. Faktor yang Membuat Putusan Pengadilan Dapat Berbeda Mengenai

\section{Pengadilan Agama}

1. Batasan dalam membuat klausa (kebebasan berkontrak) pada sebuah perjanjian

a. Kebebasan Berkontrak Menurut Kitab Undang-Undang Perdata (KUHPer)

Berdasarkan analisa awal diatas bahwa pertimbangan Hakim pada tingkat pertama dan pada tingkat Banding di Pengadilan Tinggi Agama kota Surabaya yang mengatakan bahwa Pengadilan Agama tidak berwenang untuk memutus atas dasar klausula Pasal 5 yang terdapat dalam perjanjian Akta Hibah nomor: $162 / \mathrm{Klj} / 11 / 1999$ tersebut yang mengatakan "Kedua belah pihak dalam hal ini dengan segala akibatnya memilih tempat kediaman hukum yang umum dan tidak berubah oada Kantor Kepaniteraan Pengadilan Negeri di Malang" sebagai dasar Hakim memutus tidak berwenang pada Pengadilan Agama.

Maka perlu dianalisa dengan cermat mengenai batasan kriteria sebuah klausul yang dapat dikatakan pantas dalam menjaga sebuah keadilan yang menjadi dasar dari ideologi sebuah hukum. Pada dasarnya setiap orang bebas melakukan perjanjian. Hal ini sebagai realisasi dari asas kebebasan berkontrak. Kebebasan berkontrak pada dasarnya adalah implementasi dari alam pikiran faham individualis.
Asas kebebasan berkontrak pada prinsipnya sebagai sarana hukum yang digunakan subjek hukum untuk memperoleh hak kebendaan dan mengalihkan hak kebendaan demi pemenuhan kebutuhan diri pribadi subjek hukum. Dalam KUHPerdata yang menganut sistem Eropa Kontinental kebebasan untuk melakukan kontrak dan menentukan isi kontrak dapat dilihat dalam Pasal 1338 ayat (1) KUHPerdata ${ }^{8}$.

Wujud kebebasan berkontrak baru dapat diketahui dalam praktiknya pada saat melakukan perjanjian. Dalam memenuhi kebutuhan manusia, termasuk kebutuhan akan benda ekonomi, peranan perjanjian ini sangat penting karena perjanjian oleh hukum disebutkan sebagai titel untuk memperoleh hak kepemilikan. Asas kebebasan berkontrak menurut hukum perjanjian Indonesia meliputi ruang lingkup sebagai berikut: ${ }^{9}$

a. kebebasan untuk membuat atau tidak membuat perjanjian;

b. kebebasan untuk memilih pihak dengan siapa ia ingin membuat perjanjian;

c. kebebasan untuk menentukan atau memilih kausa dari perjanjian yang dibuatnya;

d. kebebasan untuk menentukan objek perjanjian;

e. kebebasan untuk menentukan syaratsyarat suatu perjanjian termasuk kebebasan untuk menerima atau menyimpangi ketentuan undang-undang

8 Abdullah Tri Wahyudi, Peradilan Agama di Indonesia, (Yogyakarta: Pustaka Pelajar, 2004), hlm. 87.

9 Wirjono Projodikoro, Asas-asas Hukum Perjanjian, (Bandung: Mandar Maju, 2000), hlm. 284. 
yang bersifat opsional (aanvullend, optional).

Namun, di mata hukum tidak semata-mata bebas adalah tanpa sebuah batasan. Pembatasan terhadap asas kebebasan berkontrak juga dapat disimpulkan melalui Pasal 1338 ayat (3) (KUHPerdata) yang menyatakan bahwa suatu perjanjian hanya dilaksanakan dengan itikad baik. Oleh karena itu para pihak tidak dapat sesuka hati menentukan klausul-klausul yang terdapat dalam perjanjiian tetapi harus didasarkan dan dilaksanakan dengan itikad baik.

Perjanjian yang didasarkan pada itikad buruk mempunyai akibat hukum perjanjian tersebut dapat dibatalkan. Dengan demikian asas kebebasan berkontrak yang terdapat dalam Pasal 1338 KUHPerdata tidak lagi bersifat absolut, yang berarti dalam keadaan tertentu hakim berwenang melalui tafsiran hukum untuk meneliti dan menilai serta menyatakan bahwa kedudukan para pihak dalam suatu perjanjian berada dalam keadaan yang tidak seimbang sedemikian rupa, sehingga salah satu pihak dianggap tidak bebas untuk menyatakan kehendaknya.

Hal ini sesuai dengan putusan Hakim pada tingkat Kasasi dimana Hakim mengatakan bahwa " Pasal 1338 KUHPerdata tersebut tidak dapat diterapkan pada Pasal 5 akta hibah yang dibuat antara para Penggugat dengan Tergugat I karena klausul Pasal 5 akta hibah tersebut bertentangan dengan Pasal 49 Undang-undang Nomor 7 Tahun 1989 sebagaimana yang telah diubah dengan
Undang-undang Nomor 3 Tahun 2006, dan perubahan kedua dengan Undang-undang Nomor 50 Tahun 2009".

Kebebasan berakad/kontrak (mabda Hurriyyah at Ta'aqud) diakui dalam hukum Islam. Kebebasan berakad merupakan prinsip hukum yang menyatakan bahwa setiap orang dapat membuat akad jenis apapun tanpa terikat pada nama-nama yang telah ditentukan dalam undang-undang syariah dan memasukan klausul apa saja ke dalam akad yang dibuatnya itu sesuai dengan kepentingannya sejauh tidak berakibat makan harta bersama dengan jalan batil.

Aturan dalam Al-Quran dan Sunnah Nabi Muhammad SAW sebagai otoritas utama sumber hukum Islam serta kaidah-kaidah hukum Islam menunjukan bahwa hukum Islam menganut asas kebebasan berakad. Asas kebebasan ini merupakan konkritisasi labih jauh dari spesifikasi yang lebih tegas lagi terhadap asas ibahah dalam bermuammalah. Dalam Firman Allah (QS. 5:1):

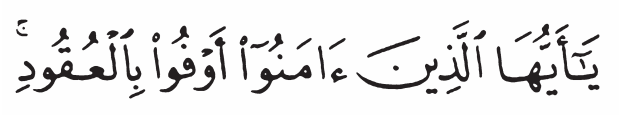

Artinya: Wahai orang-orang yang beriman, penuhilah akad-akad (perjanjianperjanjian)......

Ayat ini memerintahkan kaum mu'minin untuk memenuhi akad-akad. Menurut kaidah ushul fikih (metodologi penemuan hukum Islam), perintah dalam ayat ini (kata: aufu) menunjukan wajib. Artinya memenuhi akad itu hukumnya wajib. Dalam ayat ini "akad" 
disebutkan dalam bentuk jamak yang diberi kata sandang "al" (al-aqadàal-uqud). Menurut kaidah usul fikih, jamak yang diberi kata sandang "al" menunjukan makna umum. Dengan demikian, dari ayat tersebut dapat disimpulkan bahwa orang dapat membuat akad apa saja baik yang bernama maupun yang tidak bernama dan akad-akad itu wajib dipenuhi.

Di samping itu, ada kaidah hukum Islam yang berbunyi, "pada asasnya akad itu adalah kesepakatan para pihak dan akibat hukumnya adalah adanya apa yang mereka tetapkan atas diri mereka melalui janji" Kaidah ini menunjukan adanya kebebasan berakad karena perjanjian itu dinyatakan sebagai kata sepakat para pihak dan akibat hukumnya adalah apa yang mereka tetapkan melalui perjanjian.

Namun, kebebasan membuat akad dalam Islam bukannya tidak terbatas. Kebebasan tersebut tidak boleh menimbulkan ketidakadilan bagi pihak lain. Dalam QS.4:29 Allah berfirman:

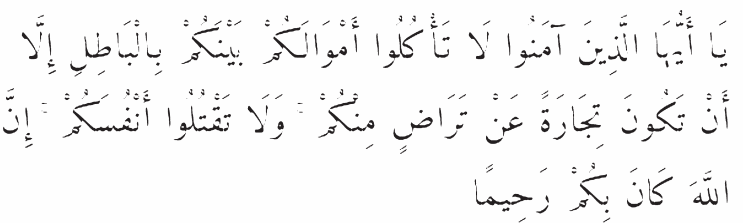

Artinya: Wahai orang-orang yang beriman, janganlah kamu makan harta sesamamu dengan jalan batil, kecuali (jika makan harta sesama itu dilakukan) dengan cara tukarmenukar berdasarkan perizinan timbal balik (kata sepakat) di antara kamu.

Yang dimaksud dengan "makan harta bersama dengan cara batil" adalah makan harta orang lain dengan cara yang tidak dibenarkan dan tidak sah menurut hukum syari'ah, baik yang dilarang secara langsung di dalam Al-Qura'an maupun berdasarkan ijtihad atas nas. Secara umum, dapat dikatakan makan harta dengan jalan batil adalah bertentangan dengan keteriban umum dan kesusilaan. Hanya saja, ketertiban dan kesusilaan dalam hukum Islam lebih luas cakupannya, karena mencakup larangan riba, gharar dan syarat peserta akad yang fasid.

Hal ini apabila ditarik kembali pada kasus Hibah dalam penelitian ini, sesuai dengan pernyataan Hakim pada tingkat Kasasi yang mengatakan, "Menimbang bahwa Pasal 210 ayat (1) Kompilasi Hukum Islam menegaskan: Orang yang telah berumur 21 tahun, berakal sehat dan tanpa paksaan dapat menghibahkan sebanyak-banyaknya sepertiga dari harta kekayaannya kepada orang lain atau lembaga di hadapan dua orang saksi untuk dimiliki. Para Tergugat tidak membantah secara tegas bahwa obyek sengketa merupakan satusatunya harta yang dimiliki para Penggugat, maka berdasarkan fakta hukum tersebut dan Akta Hibah ternyata para Penggugat memberi hibah kepada Tergugat I melebihi dari sepertiga harta kekayaannya, sehingga luas obyek sengketa yang dihibahkan bertentangan dengan hukum, oleh karena itu Akta Notaris No. 162/Klj/11/1999 tertanggal 11 Nopember 1999 yang dibuat oleh Notaris Malang Tri Sukmawati Handayani, S.H. dinyatakan cacat hukum dan tidak mempunyai kekuatan hukum”. 
"Menimbang bahwa Pasal 212 KHI menyatakan: Hibah tidak dapat ditarik kembali kecuali hibah orang tua pada anaknya, oleh karena itu tuntutan para Penggugat/ Pemohon Kasasi agar hibah sebagaimana tertuang dalam Akta Hibah No. 162/Klj/11/1999 tertanggal 11 Nopember 1999 di hadapan Notaris Malang Tri Sukmawati Handayani, S.H. dinyatakan cacat hukum dan dibatalkan adalah tuntutan yang mempunyai landasan hukum”.

Hal ini membuktikan bahwa putusan Hakim Mahkamah Agung pada tingkat Kasasi dan Peninjauan Kembali adalah tepat dan sesuai dengan aturan KUHPerdata sekaligus syari'at Islam. Sehingga dapat disimpulkan bahwa putusan Hakim pada tingkat pertama dan kedua terjadi sebuah kesalahan karena tidak sesuai dengan asas dan ideologi hukum.

\section{B. Keabsahan Akata Hibah Nomor 162/Klj/11/1999 Apabila Ditinjau dari Sudut Pandang Kompilasi Hukum Islam}

Syari'at Islam merupakan aturan hukum yang ditetapkan Allah SWT untuk kemaslahatan umat manusia. Hukum atau peraturan dalam menjalankan dan mengamalkan agama Allah SWT termasuk syari'at Islam. peraturan yang telah ditetapkan Allah SWTkepadamanusia, baikhubungannya terhadap Allah SWT, maupun hubungan terhadap sesama manusia, alam dan kehidupan.

Hukum secara umum belum mutlak dinamakan Syari'at Islam dalam era modern.
Sebab hukum yang bersumber dari Allah SWT (seperti Syari'at Islam) dinamakan hukum samawi, sedangkan hukum yang dibuat oleh manusia disebut hukum wadh'i. Syari'at Islam sebagai hukum samawi berlaku mutlak sedangkan hukum wadh'i sifatnya berlaku relatif hanya berdasarkan kepada kepentingan dan kebutuhan manusia dalam masa-masa tertentu.

Tentunya sebagai seorang muslim tidak dapat mengabaikan aturan atau syari'at Islam dalam setiap tingkah laku yang dilakukan, terutama dalam melakukan suatu perjanjian. Agama Islam memiliki cara pandang yang berbeda dalam mengatur persoalan hibah.

Dalam Al-Qur'an, penggunaan kata hibah digunakan dalam konteks pemberian anugerah Allah SWT kepada utusanutusan-Nya, doa-doa yang dipanjatkan oleh hamba-hamba-Nya, terutama para nabi, dan menjelaskan sifat Allah Yang Maha Memberi Karunia. Namun ayat ini dapat digunakan petunjuk dan anjuran secara umum, agar seseorang memberikan sebagian rezekinya kepada orang lain. Misalnya, QS. Al-Baqarah ayat $262^{10}$.

Jumhur fuqaha berpegang bahwa ijma' (kesepakatan) telah terjadi tentang yang diperbolehkan dalam Islam terhadap seseorang dalam keadaan sehatnya memberikan seluruh hartanya kepada orang asing sama sekali di luar anak-anaknya. Jika pemberian seperti ini dapat terjadi untuk orang asing, maka terlebih lagi terhadap anak. 
Alasan mereka adalah menurut Abu Bakar, bahwa ia memberi 'Aisyah pecahan-pecahan seberat 20 wasaq dari harta hutan. Pada saat menjelang wafatnya, Abu Bakar r.a. berkata: "Demi Allah, wahai anakku, tidak seorangpun yang kekayannya lebih menyenangkan aku sesudah aku selain daripada engkau. Dan tidak ada yang lebih mulia bagiku kefakirannya selain daripada engkau. Sesungguhnya aku dahulu memberimu pecahan (emas) 20 wasaq. Maka jika engkau memecah-mecah dan memilikinya, maka itu adalah bagimu. Hanya saja, harta itu sekarang menjadi harta waris"11.

Mereka berpendapat bahwa maksud hadits tersebut adalah nadb (sunnah). Yang jelas Al-Qur'an dan Hadits banyak sekali menggunakan istilah yang konotasinya menganjurkan agar manusia yang telah dikarunia rezeki itu mengeluarkan sebagiannya kepada orang lain. Kendati istilah-istilah tersebut memiliki ciri-ciri khas yang berbeda, kesamaannya adalah bahwa manusia diperintahkan untuk mengeluarkan sebagian hartanya.

Menurut jumhur ulama rukun hibah ada empat:

a. Wahib (Pemberi) adalah pemberi hibah, yang menghibahkan barang miliknya kepada orang lain.

b. Mauhublah (Penerima), Penerima hibah adalah seluruh manusia dalam arti orang yang menerima hibah. c. Mauhub adalah barang yang dihibahkan.

d. Shighat (Ijab dan Qabul) hibbah adalah segala sesuatu yang dapat dikatakan ijab dan qabul ${ }^{12}$.

Sedangkan syarat-syarat hibah yaitu Hibah menghendaki adanya penghibah, orang yang diberi hibah, dan sesuatu yang dihibahkan.

Disyaratkan bagi penghibah syarat-syarat sebagai berikut:

a. Penghibah memiliki sesuatu untuk dihibahkan

b. Penghibah bukan orang yang dibatasi haknya karena suatu alasan.

c. Penghibah itu orang dewasa, sebab anakanak kurang kemampuannya.

d. Penghibah itu tidak dipaksa, sebab hibah itu akad yang mempersyaratkan keridhaan dalam keabsahannya.

Disyaratkan bagi orang yang diberi hibah yaitu orang yang diberi hibah harus benarbenar ada waktu diberi hibah. Bila tidak benar-benar ada, atau diperkirakan adanya, misalnya dalam bentuk janin, maka hibah tidak sah. Apabila orang yang diberi hibah itu ada di waktu pemberian hibah, akan tetapi dia masih atau gila, maka hibah itu diambil oleh walinya, pemeliharaannya atau orang mendidiknya sekalipun dia orang asing ${ }^{13}$.

Selanjutnya syarat-syarat bagi yang dihibahkan, yaitu: ${ }^{14}$

a. Benar-benar ada;

b. Harta yang bernilai;

11 Ibnu Rusyd, Bidayatul-Mujtahid, Juz 4 , (Semarang: Asy-Syifa', 1990), hlm. 113.

12 Sayyid Sabiq, Fikih Sunnah 14, Terjemahan Mudzakir, (Bandung: Al Ma'arif, 1987), hlm. 178.

13 R. Subejti, Aneka Perjanjian, (Bandung: Citra Aditya Bakti, 1995), hlm. 95.

14 C. S. T. Kansil, Pengantar Ilmu Hukum Dan Tata Hukum Indonesia, (Jakarta: Balai Pustaka, 2002), hlm. 252. 
c. Dapat dimiliki zatnya, yakni bahwa yang dihibahkan itu adalah apa yang bisa dimiliki, diterima peredarannya, dan pemilikannya dapat berpindah tangan. Maka tidak sah menghibahkan air di sungai, ikan di laut, burung di udara, masjid-masjid atau pesantren-pesantren;

d. Tidak berhubungan dengan tempat pemilik hibah, seperti menghibahkan tanaman, pohon, atau bangunan tanpa tanahnya;

e. Dikhususkan, yakni yang dihibahkan itu bukan untuk umum, sebab pemegangan dengan tangan itu tidak sah kecuali bila ditentukaan (dikhususkan) seperti halnya jaminan $^{15}$

Berdasarkan pandangan Islam atas pemahaman serta syarat dari penghibah dan pihak yang diberi hibah apabila dikaitkan dengan Akta Hibah Nomor 162/Klj/11/1999, maka dalam Akta Hibah tersebut yang berperan sebagai Pemberi Hibah adalah $\mathrm{H}$. Achmad Jakoen Tjokrohadin bin Achmad Tohir beserta istri kepada pihak Penerima Hibah yang berposisi anak kandung dari Pemberi Hibah yaitu Dra. Ani Hadi Setyowati alias Ani Indra Sudibyo binti H. Achmad Jakoen.

Bahwasannya Akta Hibah Nomor 162/ $\mathrm{Klj} / 11 / 1999$ telah memenuhi syarat awal dari proses hibah, yaitu terpenuhinya unsur adanya pihak-pihak mulai dari Pemberi Hibah dan Penerima. Selanjutnya, dilihat dari syarat mengenai obyek yang di hibahkan, yaitu yang dalam perkara ini merupakan tanah dan bangunan seluas $983 \mathrm{~m} 2$ di Jl. Diponegoro No. 02 RT. 01, RW 05, juga telah terpenuhi karena obyek tersebut telah ada pada saat hibah berlangsung dan diberikan pada pihak yang benar-benar ada pada saat hibah tersebut berlangsung.

Namun tidak berhenti pada aturan dasar tersebut karena apabila ditinjau dari aturan dalam Pasal 210 ayat (1) Kompilasi Hukum Islam yang menegaskan " Orang yang telah berumur 21 tahun, berakal sehat dan tanpa paksaan dapat menghibahkan sebanyakbanyaknya 1/3 harta bendanya kepada orang lain atau lembaga di hadapan dua orang saksi untuk dimiliki" tersebut ada hal inti yang terabaikan dalam Akta Hibah Nomor 162/ Klj/11/1999.

Hal tersebut adalah mengenai porsi obyek hibah yang diberikan kepada salah satu anak dari 8 (delapan) bersaudara tersebut, obyek hibah tersebut diketahui merupakan satusatunya harta dari Pemberi Hibah, maka berdasarkan fakya hukum tersebut maka Akta Hibah tersebut cacat secara hukum karena tidak sesuai dengan aturan dalam Kompilasi Hukum Islam.

Terdapat dua hal yang hendak dicapai oleh hibah yakni, Pertama, dengan memberi akan menimbulkan suasana akrab dan kasih sayang antara sesama manusia. Sedangkan mempererat hubungan silaturrahmi itu termasuk ajaran dasar agama Islam. Kedua, yang dituju oleh anjuran hibah adalah 
terbentuknya kerjasama dalam berbuat baik, baik dalam menanggulangi kesulitan saudaranya, maupun dalam membangun lembaga-lembaga sosial ${ }^{16}$.

Berlanjut pada aturan dalam Kompilasi Hukum Islam, yaitu dalam Pasal 212 Kompilasi Hukum Islam yang berbunyi "Hibah tidak dapat ditarik kembali, kecuali hibah orang tua kepada anaknya". Berdasarkan aturan Kompilasi Hukum Islam tersebut sangat jelas dikatakan bahwa hibah yang berasal dari orang tua kepada anaknya dapat dengan sah untuk ditarik kembali.

Apabila dikaitkan pada Akta Hibah Nomor $162 / \mathrm{Klj} / 11 / 1999$, mengingat tentang perihal utama yaitu tujuan dari dilakukannya Hibah adalah untuk mempererat tali persaudaraan dan sebagai bentuk kasih sayang maka hasil yang diwujudkan oleh Akta Hibah ini sangatlah bertentangan dan tidak sejalan dengan tujuan hakiki sebuah Hibah.

Selain itu mengingat bahwa dalam kasus ini pihak Pemberi Hibah merupakan orang tua kandung dari pihak Penerima Hibah maka sangat diperbolehkan dan sah secara Hukum Islam berdasarkan Pasal 212 Kompilasi Hukum Islam apabila pihak Pemberi Hibah merasa ingin menarik Hibah yang telah diberikan dan seharusnya pihak Penerima Hibah dapat berlapang dada dan ikhlas dalam perihal penarikan hibah tersebut.

Hibah Menurut aturan hukum Islam dapat dilakukan baik secara tertulis maupun lisan, bahkan telah ditetapkan dalam Hukum Islam, pemberian yang berupa harta tidak bergerak dapat dilakukan dengan lisan tanpa mempergunakan suatu dokumen tertulis. Namun jika ditemukan bukti-bukti yang cukup tentang terjadinya peralihan hak milik, maka pemberian tersebut dapat dinyatakan secara tertulis. Jika pemberian tersebut dilakukan dalam bentuk tertulis, bentuk tersebut terdapat dua macam yaitu: ${ }^{17}$

1. Bentuk tertulis yang tidak perlu didaftarkan, jika isinya hanyamenyatakan bahwa telah terjadinya pemberian;

2. Bentuk tertulis yang perlu didaftarkan, jika surat tersebut merupakan suatu alat dari penyerahan pemberian itu sendiri. Artinya, apabila penyerahan dan pernyataan terhadap benda yang bersangkutan kemudian disusul oleh dokumen resmi tentang pemberian, maka yang demikian itulah yang harus didaftarkan.

Islam merupakan agama yang tidak ingin menyusahkan umatnya, namun Islam juga meyukai kemaslahatan bagi setiap umatnya. Kemaslahatan di sini yaitu apabila ada upaya yang dapat memberi manfaat lebih maka Islam menganjurkannya, termasuk dalam persoalan Akta Notariil.

Seperti yang telah diketahui bahwa salah satu kegunaan dari sebuah Akta Notariil yaitu merupakan sebuah bukti otentik atau sebuah bukti yang memiliki kekuatan hukum, maka

16 Satria Effendi M. Zein, Problematika Hukum Keluarga Islam Konteporer, (Jakarta: Kencana, 2004), hlm. 471472. 
dari itu Islam tidak ada larangan apabila umatNya hendak melakukan hibah dengan cara Akta Notariil demi kemaslahatan bersama atau demi suatu bukti pertanggungjawaban apabila dikemudian hari terjadi sesuatu yang tidak dikehendaki oleh para pihak.

\section{Simpulan}

Bahwa ada beberapa faktor yang menjadi permasalahan hukum mengenai proses peradilan di Pengadilan Agama mengalami suatu kesalahan interpretasi dan beberapa hal yang perlu dicermati perihal Hibah:

1. Mengenai faktor yang membuat terjadinya suatu kesalahan dalam Pengadilan Agama dalam memutus perkara pembatalan Akta Hibah:

a. Bahwa hibah tidak hanya diatur dalam Kitab Undang-Undang Hukum Perdata (KUHPerdata) mulai Pasal 1666 hingga 1693 BW, namun apabila dalam Hukum Islam hibah juga diatur dalam Pasal 210 hingga 214 Kompilasi Hukum Islam (KHI).

b. Bahwa telah terjadi suatu kesalahan dalam Putusan pada tingkat pertama dan kedua, karena tidak sesuai dengan aturan dalam Perundang-undangan dan hal ini dikuatkan dengan putusan Hakim pada tingkat Mahkamah Agung (MA) dengan amar Hakim pada tingkat Kasasi dimana Hakim mengatakan bahwa " Pasal 1338 tersebut tidak dapat diterapkan pada Pasal 5 akta hibah yang dibuat antara para Penggugat dengan Tergugat I karena klausul Pasal 5 akta hibah tersebut bertentangan dengan Pasal 49 Undang-undang Nomor 7 Tahun 1989 sebagaimana yang telah diubah dengan Undang-undang Nomor 3
Tahun 2006, dan perubahan kedua dengan Undang-undang Nomor 50 Tahun 2009".

c. Adanya pertimbangan mengenai kebebasan berkontrak dalam pembuatan Akta Hibah, bahwa diketahui kebebasan berkontrak juga memiliki batasan-batasan, sehingga tidak melampui Undang-undang yang telah mengaturnya. Bahwa adanya Pasal 5 dalam Akta Hibah nomor: $162 / \mathrm{Klj} / 11 / 1999$ yang melampui atau tidak dapat diterapkan karena berbenturan dengan aturan Pasal 49 dalam Undang-undang Peradilan Agama. Selain itu adanya batasan legitime portie dalam hibah.

d. Bahwa dalam kasus ini yang kedua belah pihak yaitu si Pemberi Hibah dan Penerima Hibah seluruhnya merupakan seorang muslim maka sepenuhnya Pengadilan Agama berwenang dalam memutus perkara Pembatalan Akta Hibah dan secara otomatis pertaruran dalam Kompilasi Hukum Islam juga harus turut diperhatikan.

2. Akta Hibah memiliki sudut pandang yang berbeda dalam aturan Kompilasi Hukum Islam dengan aturan dalam Burgelijk Wetboek, yaitu dalam hal:

a. Dalam Islam tidak mengenal legitime portie namun dalam Islam dikenal adanya Hak Bagian, hal ini ditegaskan dalam aturan Kompilasi Hukum Islam (KHI) Pasal 210 Kompilasi Hukum Islam yang berbunyi “ Orang yang telah berumur sekurang-kurangnya 21 tahun berakal sehat tanpa adanya paksaan dapat menghibahkan sebanyak-banyaknya $1 / 3$ harta bendanya kepada orang lain atau lembaga di hadapan dua orang saksi untuk dimiliki”. 
b. Bahwa Kompilasi Hukum Islam bukanlah merupakan sumber hukum, karena sesungguhnya sumber hukum dalam Islam tetaplah Al-Qur'an dan Al Hadist Nabi Muhammad SAW, sedangkan Kompilasi Hukum
Islam merupakan Bahan Hukum pendukung utama yang digunakan dalam Peradilan Agama berdasarkan Instruksi Presiden Nomor 1 Tahun 1991 tentang Penyebarluasan Kompilasi Hukum Islam (KHI).

\section{DAFTAR PUSTAKA}

\section{Buku}

Al-Jaziry, Abdurahman. Kitab Fiqhi 'ala al-Mazhabai al Arba'ah, Dar Al-Fikr. Beirut: Maktabat At-Tijariyah, 1987. Arikunto, Suharsimi. Prosedur Penelitian: Suatu Pendekatan Praktek. Jakarta: Rieneka Cipta, 2002.

Bungin, Burhan. Metodologi Penelitian Kualitatif: Aktualisasi Metodologi Ke arah Ragam Varian

Kontemporer. Jakarta: RajaGrafindo Persada, 2007.

Fayzee, A. A. Pokok-Pokok Hukum Islam II. Jakarta: Tintamas, 1961.

Harsono, Boedi. Hukum Agraria Indonesia (Sejarah Pembentukan Undangundang Pokok Agraria, Isi, dan Pelaksanaannya). Jakarta: Djambatan, 2003.

Hidjaz, Kamal. Efektivitas Penyelenggaraan Kewenangan Dalam

Sistem Pemerintahan Daerah Di Indonesia. Makasar: Pustaka Refleksi, 2010 .

HR, Ridwan. Hukum Administrasi Negara. Jakarta: RajaGrafindo Persada, 2013.
Ibrahim, Jhonny. Teori dan Metodologi Penelitian Hukum Normatif. Malang: Bayumedia Publishing, 2006.

Kansil, C.S.T. Pengantar Ilmu Hukum Dan Tata Hukum Indonesia. Jakarta: Balai Pustaka, 2002.

Marzuki, Peter Mahmud. Penelitian Hukum. Jakarta: Kencana Prenada Media Group, 2005.

Muhammad, Abdulkadir. Hukum dan Penelitian Hukum. Bandung: Citra Aditya Bakti, 2004.

Munawwir, Ahmad Warson. Kamus Al-Munawwir. Surabaya: Pustaka Progressif, 1997.

Pasaribu, Chairuman, Lubis, Suhrawadi K. Hukum Perjanjian Dalam Islam. Jakarta: Sinar Grafika, 1994.

Rofiq, Ahmad. Hukum Islam Di Indonesia. Jakarta: RajaGrafindo Persada, 1995.

Sabiq, Sayyid. Fikih Sunnah 14. Terj: Mudzakir. Bandung: Al Ma’arif, 1987.

Subejti, R. Aneka Perjanjian. Bandung: Citra Aditya Bakti, 1995.

Subekti, R. Tjitrosudibio, R. Kitab UndangUndang Hukum Perdata. Jakarta: Pradnya Paramita, 1979. 
Soekanto, Soerjono. Pokok-Pokok Sosiologi Peraturan Perundang-undangan

Hukum. Jakarta, RajaGrafindo Persada, Kitab Undang-undang Hukum Perdata 2002.

(KUHPerdata).

Soekanto, Soerjono dan Sri Mamudji. Kompilasi Hukum Islam (KHI).

Penelitian Hukum Normatif Tujuan Undang-undang Nomor: 50 Tahun 2009 Singkat. Jakarta: Rajawali Pers, 2006.

tentang Peradilan Agama.

Tutik, Titik Triwulan. Pengantar Ilmu Hukum.

Jakarta: Prestasi Pustakaraya, 2006.

\section{Makalah}

Saifullah. Konsep Dasar Metode Penelitian Dalam Proposal Skripsi. Hand out. Fakultas Syariah UIN Malang, 2004. 